\title{
As Drogas e as Psicoses: sobre a constituição do delírio e as toxicomanias
}

Carlos Eduardo de A.S. Ramos ${ }^{1}$

\section{Introdução}

A principal questão levantada no presente trabalho surgiu diante da seguinte situação: num estágio voluntário dentro de um hospital psiquiátrico, onde passei 6 meses permanecendo 12 horas semanais, tive a oportunidade de estabelecer um bom contato com alguns pacientes. Dentre eles havia E.: uma mulher que provavelmente tinha mais de 50 anos de idade, usuária do Sistema Único de Saúde, tratando-se na unidade de hospital dia. Não cabe aqui um estudo de caso, até por que o estágio não possibilitava acesso a histórico médico ou quaisquer registros, e a informação que tinha dessa paciente era somente essa, além das que provinham da sua fala (no caso desse trabalho, talvez a melhor possível). Era uma pessoa religiosa. Certo dia, durante uma conversa, ela começou a falar sobre como Deus tinha iluminado sua vida, e como isso era valoroso e importante para ela. De certa forma ela sempre referia-se a esses aspectos, mas neste dia ela começou a falar sobre como essas experiências tinham acontecido na sua infância, o que para mim era algo completamente novo. Então: sua primeira iluminação teria acontecido quando ainda era bem nova, ajudava seu pai nos afazeres, inclusive na manutenção de um campo de bocha, onde nos finais de semana os amigos de seu pai se encontravam para jogar. Relatou-me que de noite, quando iam arrumar o campo de bocha, havia uma coruja que ficava rondando por ali. Essa coruja lhe dizia: Luz! Luz!...Luz!. Não sabia ela porque a coruja dizia isso, mas descobriu pouco tempo depois que não era somente uma coruja, era uma espécie de bola de bocha viva que se desviava não deixando que nenhuma outra a acertasse. E nisso consistia sua grande iluminação que, na sua fala, modificou todo o curso de sua vida.

Bem, digamos que no que dizia respeito a mim, ali naquela situação, puxei a conversa para que ela me explicasse, me contasse o que tinha acontecido. Sentia que era algo importante para tal pessoa, talvez pela expressividade não somente de seus olhos e gestos, mas também ao perceber uma certa agitação quando começou a me contar mais detalhadamente (chegou a se levantar num dado momento de sua fala, gesticulando bastante). No entanto, algo surge para mim como questão, pois não estava muito seguro do que eu estava fazendo ao me interessar. Dito isso, a questão que se me levanta seria: o que eu estava 'fazendo' ali? O que houve quando essa mulher me

' Graduação - Psicologia UFPR 
contou essa história emocionadamente e, eu, tendo uma nítida sensação de que algo pelo menos bem importante tinha acabado de acontecer com ela, não fazia a menor idéia de que função tive 'eu' para ela, se é que tive? Por mais que logo de início percebesse algum grau de intensidade e importância no que ela me dizia (e creio que tive êxito em deixá-la dizer), em um dado momento do diálogo essa pergunta se colocou para mim: que diabos está acontecendo aqui? Eu não sabia o que estava fazendo, nesse sentido que quero dar ao que eu estava fazendo, algo que acontecia além do fato de escutá-la e de certa forma viabilizar sua fala, perguntando sinceramente onde não tinha ficado claro para mim no que ela dizia, interessando-me pelo que ela dizia...

Tratando-se o presente trabalho de uma explanação psicanalítica sobre o tema, caberia aqui tentar nomear melhor a questão usando-se dos nomes que o saber psicanalítico nos proporciona. Uma maneira de localizar a questão seria uma pressuposição que tinha e que é importante fixar, não como certeza, mas como hipótese diagnóstica através da qual o trabalho guiar-se-á. Tal suposição é a de que aquilo que falava-me era uma estrutura psicótica, seja lá o que isso exatamente queira dizer. Porque fazia tal suposição? Muito do que minha curiosidade achava nos livros, nas aulas, nas conversas com professores sobre isso que denominou-se para a psicanálise como psicose, eu cria que encontrava ali. Além disso, é importante frisar, nessa época eu estava realizando um trabalho de pesquisa sobre as toxicomanias e a constituição do delírio na psicose, o que já me possibilitou entender um pouco melhor alguns desses pontos (Ramos, 2001). Sendo assim, dentre tais nomes: supus também que tratava-se ali de algo da ordem do que é chamado de constituição do delírio para a psicose. Considerei alguns aspectos, tais como: aquela fala sobre a iluminação e como foram os acontecimentos relatados por ela, a voz ouvida e atribuída à coruja, a forma como relata, o fato de se tratar de uma iluminação divina, que modificara todo o curso de sua vida, ou seja, os efeitos da fala ouvida na coruja, e mesmo um aspecto de seu 'dizer', que consiste no fato de que ela passava-me uma certa impressão de não controlar a própria fala. A partir desses pontos supus estar diante de uma formação delirante. Por enquanto não cabe explicar melhor essa terminologia, pois parte do trabalho consistirá em tentar definir um pouco melhor esses conceitos. Outro nome que fazia algum sentido era algo como 'função de escuta'. Da mesma forma, tinha alguma noção e suposição sobre o que era que eu estava efetuando ali, possibilitando aquela fala. Tentando reescrever a pergunta: que será essa função de escuta na situação própria da constituição de um delírio para a psicose? O que é que o analista faz, se é que faz algo, nessa situação?

Talvez seja melhor definir a questão do trabalho como uma questão de direção no tratamento: o que fazer quando diante de um delírio. Compreende-se 
tal como uma questão técnica, não perdendo de vista que para a psicanálise a técnica e a ética estão mutuamente implicadas.

Ao mesmo tempo que algo escapava-me no que estava acontecendo ali, eu não tinha muita clareza de o que fazer. Tinha algumas noções, que principalmente iam de encontro com o que a supervisão dada no hospital me dizia que era para 'fazer', mas nada que me desse uma confiança, que me possibilitasse dessa forma Ter mais clareza no que eu estava fazendo. Dessa forma o trabalho também tem uma importância a nível de experiência e aprendizado clínico, procurando responder, da forma como for possível, que rumo deve-se Ter, que direção tomar quando diante de uma construção delirante.

O presente trabalho pretende explorar melhor essas questões seguindo o plano de trabalho abaixo:

1) Considerações (esboços) iniciais sobre a função do delírio na psicose

Tenta-se introduzir a questão do delírio para a estrutura psicótica, considerando-se alguns parâmetros essenciais para a psicanálise e a forma como esta compreende os fenômenos mentais. A obra abordada aqui é o seminário 3 sobre as psicoses, de Lacan (1955).

2) Estudo do texto "Sobre a Psicoterapia".: linhas gerais e definições para se conceber a técnica da psicanálise e seus princípios

A partir da leitura do texto (Freud, 1905), pretende-se adentrar na técnica da psicanálise e acompanhar o desenvolvimento do autor no que concerne às direções e possibilidades no tratamento analítico, para que se possa conceber uma direção quando diante do delírio.

3) Estudo do texto "Sobre o Início do Tratamento (novas recomendações sobre a técnica da psicanálise I)".: do que diverge e do que converge na técnica

A diferenciação da técnica para uma e para outra estrutura (neurose e psicose) torna-se um foco necessário. No entanto essa diferença é um efeito da própria estrutura que chega-nos. Isso significa que a técnica deve acompanhar a estrutura, e aqui tenta-se introduzir essa problemática no que diz respeito à psicose. (Freud, 1913)

4) Estudo do texto "Sobre o narcisismo: uma introdução".: características essenciais do investimento libidinal e conceituação de introversão nas estruturas clínicas

Depois de acompanhar textos mais técnicos, faz-se necessário compreender a metapsicologia das psicoses. Nesse texto o autor dá linhas gerais, no entanto decisivas, para a compreensão da psicose (e do delírio) a luz da teoria da libido.(Freud, 1914) 
1) Considerações (esboços) iniciais sobre a função do delírio na psicose

É primordial para o trabalho que se tente esclarecer um pouco melhor isso que está sendo nomeado como delírio.

Voltando-se ao que a senhora E. havia dito-me naquela ocasião: uma coruja Ihe dizia: Luz! Luz! É importante enfatizar aqui que a entonação de voz que ela dava ao dizer essas palavras era, para meus ouvidos, muito próximo ao som emitido por uma coruja. Se o leitor já ouviu uma coruja, tente ouvir a palavra 'luz' em meio ao som e verá que é perfeitamente passível, e inclusive soa, ao menos para mim, como criação poética. Uma coruja que no seu canto falava 'luz'. Mas de fato, para a senhora E. não parecia tratar-se de uma criação poética. Não foi-me dito com nenhum tom de metáfora, de qualquer ironia, ou sequer de representação de uma experiência mística que the revelou, na interpretação que fizera, alguma outra coisa além da experiência. Excluo aqui essas possibilidades, pois não parecia tratar-se de quaisquer desses acontecimentos que, se não nos acontece, ao menos ouvimos falar, e nem por isso achamos que os poetas são psicóticos. Ela realmente ouviu a coruja dizerIhe 'luz'. Temos aqui condições para acreditar que tratava-se de uma alucinação.

Outra característica que chamava-me a atenção na sua fala, era o fato de que ela não abordava-me com nenhuma questão. A fala dela parecia ser direcionada para mim: ela falava para mim e não comigo. Quero dizer que, de certa forma, não havia aquele elemento tão comum nos diálogos (do tipo: concorda? O que você acha? Ou quaisquer interpelações desse tipo), e assim dava uma impressão de que ela não me abordava como interlocutor. No máximo fora eu quem perguntei coisas para ela, que somente se aproximava e contava estórias e coisas.

Para introduzir a noção do que é o delírio, faz-se necessário explicar um pouco melhor o que é a alucinação. Isso por que posteriormente poderemos compreender que a condição da alucinação é essencial para a criação delirante, o delírio teria como fundamental a alucinação. Aqui, proponho a leitura de um parágrafo do Seminário sobre as psicoses de Lacan:

Eu a indiquei para vocês já na última vez ao lembrar-lhes o caráter central da alucinaçāo verbal na paranóia. [grifo meu] Vocês sabem o tempo que se levou para perceber o que é no entanto algumas vezes inteiramente visível, ou seja, que o sujeito articula o que ele diz ouvir. [grifo meu] Foi preciso o Sr. Séglas e seu livro as 'liçōes clínicas'. Por uma espécie de lance notável no início de sua carreira, ele notou que as alucinações verbais se produziam em pessoas em quem se podia perceber, com sinais muito evidentes em certos casos, e em outras observando-as um pouco mais atentamente, que elas próprias estavam articulando, sabendo ou não, ou não querendo 
sabê-lo, as palavras que eles acusavam as suas vozes de as terem pronunciado. Isso constituiu uma pequena revolução, a de perceber que a alucinação auditiva não tinha sua origem no exterior: [grifo meu] (Lacan, 1955, p.33)

O que mais nos vale aqui como central no raciocínio que se seguia são as duas primeiras frases. O que foi grifado diz que a alucinação é algo central na paranóia, entendendo aqui que o dito delírio tem uma relação direta com isso que é 'diagnosticado' como paranóia. No segundo trecho grifado, parece seguir a explicação de porque é central, e diz-nos que o sujeito articula o que diz ouvir. Certamente, o que o presente trabalho conceitua como delírio seria essa 'articulação' a qual o sujeito faz do que houve no registro Real, e que lhe permite apropriar-se, dizer o que ouve (houve?) ao invés de simplesmente ouvir como voz que se lhe impõe. É possível que ele (o sujeito psicótico) diga, a partir de então, o que ouviu. 'O sujeito articula o que ele diz ouvir' e talvez fosse impossível de dizer se não houvesse essa articulação do sujeito.

Outro aspecto de muita importância está na última frase do texto citado. Nas 'Lições clínicas' de Séglas, abre-se a possibilidade de um novo dado na compreensão da alucinação auditiva: ela não tinha origem no exterior. Isso é crucial para que possamos compreender o nível 'mental' da alucinação, ou seja, passar a compreender este fenômeno não só a partir da fisiologia, do dado biológico, mas incluir o nível mental do fenômeno, e, a partir da psicanálise, poder compreender a implicação desse inconsciente, característico da criação freudiana, na alucinação e também no delírio.

Se podemos fazer uso disso para compreender, no que diz respeito a senhora E.: não pode-se saber o que definitivamente ela ouviu, mas ela nos diz que uma coruja que sempre rondava por ali quando de noite ajudava o pai a arrumar o campo de bocha, essa coruja foi que lhe disse, e que não era simplesmente uma coruja, e assim continua: a coruja era uma bola de bocha... Podemos supor que uma voz surgiu como alucinação, e a senhora E. articula dessa forma, e diz essa forma, essa construção sobre o que foi que ela ouviu.

$\mathrm{O}$ que se pretende nesse trabalho é tentar aprofundar um pouco a noção, e o porquê, de que nessa situação em que o sujeito articula aquilo que ele ouve no registro Real, aquilo que ele alucina, ele está criando uma metáfora. Trata-se de certa forma de uma hipótese: o que o sujeito alucina não é metáfora, mas ao articular o que diz, cria uma. Vejamos bem, essa criação é diferente da metáfora para o neurótico, em que essa seria o efeito de algo anterior. Aqui fala-se de criação mesmo, e de que o delírio seria construído a partir destas 'metáforas' criadas. O delírio seria a construção toda de uma significação fundamentada, ou ao menos referenciada, a essas palavras chave, que na verdade são palavras de estatuto completamente diferente. É sobre, a partir de o que o sujeito ouve e articula na alucinação, que ele cria originalmente todo um mundo de significação próprio. 
Bem... temos muitos conceitos complexos aqui envolvidos. E parece que se quer concluir o trabalho antes mesmo de começá-lo.

Para tentar obter um pouco mais de subsídios na compreensão do delírio, da forma como o psicótico 'representa' a realidade, e também de que função este delírio tem para a estrutura psicótica, e quais as diferenças entre esta e a neurose, proponho uma leitura freudiana. A questão é que ler o texto lacaniano sem o fundamento freudiano parece suicídio, não se consegue localizar direito a fala do autor, e consequentemente não se consegue compreender o que ele nos diz.

Além disso, temos algumas questões centrais no trabalho. E essas giram em torno do delírio e de suas implicações na prática clínica. Isso nos leva a direcionar as questões principalmente para: o que é o delírio? O que é a prática clínica?. Somente depois disso poderemos formular a pergunta? Como trabalhar clinicamente com o delírio?

2) Estudo do texto "Sobre a Psicoterapia".: linhas gerais e definições para se conceber a técnica da psicanálise e seus princípios.

A questão das psicoses interessa o presente trabalho de um ponto de vista bastante clínico. Busca-se compreender o que acontece aí onde o psicótico fala, e quando num encontro com um analista. De fato, trata-se também de explorar sobre o que o saber psicanalítico pode, em relação a essa estrutura clínica.

Para começarmos a falar seriamente sobre o que acontece clinicamente com a psicose, uma possibilidade de ponto de partida seriam os textos freudianos sobre a técnica, e é por aí que o trabalho proporá um caminho. Em 'Sobre a Psicoterapia' é possível que encontremos algo. Trata-se de um texto onde o autor fala de regras que ele tem para empreender a psicoterapia em seus pacientes, mas que em vários momentos deixa claro que não se tratam de regras fixas que não podem ser repensadas, até por que fala mais do seu estilo de trabalho do que de um modelo de técnica a qual deve ser seguida a risca. Desta forma, temos um trecho intrigante onde Freud escreve:

(2) Quando se quer trabalhar em segurança, deve-se restringir a escolha a pessoas que tenham um estado normal, pois é neste que nos apoiamos, no procedimento psicanalítico, para nos apropriarmos do patológico. As psicoses, os estados confusionais $e$ a depressão profundamente arraigada (tóxica, eu poderia dizer), por conseguinte, são impróprios para a psicanálise, ao menos tal como tem sido praticada até o momento. [grifo meu] Não considero nada impossível que, mediante uma modificação apropriada do método, possamos superar essa contra-indicação e assim empreender a psicoterapia das psicoses. (Freud, 1905, p. 247)

O que a primeira vista chama a atenção é que o autor nos diz claramente que as psicoses seriam impróprias para a psicanálise. Isso surte 
efeito no leitor, por mais que em seguida ele esclareça que trata-se de uma impossibilidade a qual ele não considera como limite intransponível. Escreve que mediante uma adaptação do método, essa situação pode mudar.

Bem, daqui podemos seguir com algumas questões. Dentre elas, duas parecem importantes: $\mathrm{O}$ que ele está chamando de 'psicanálise praticada até o momento'? E por que essa psicanálise não se aplica às psicoses?

Essas duas questões tocam o trabalho de que forma? Se perguntamonos o que acontece na clínica das psicoses, mais especificamente na escuta de um delírio, que é a questão do trabalho, parece que Freud quer dizer-nos que algo não acontece? Não sabemos direito do que ele fala. Por outro lado, em decorrência disto, ele diz que essa técnica até agora elaborada não tem efeitos nas psicoses, enquanto outra questão do trabalho é exatamente 'o que fazer quando diante de um delírio?', ou seja: “como Ter efeitos quando diante do delírio?'.

Aqui faz-se necessário uma contextualização mínima, e esta nos remete ao fato de que, primeiramente, trata-se de um texto de 1905, quando toda a psicanálise ainda era muito nova mesmo para o próprio Freud. Além disso: é importante que dialoguemos com outros textos da mesma época para podermos apreender melhor o que o autor quer passar para o leitor.

Pode-se construir hipóteses, ou meros pontos de apoio, para tais perguntas incitadas pelo trecho analisado. Uma delas é o fato de que Freud, nessa época, fala e trata essencialmente do que ele chamou de neuroses, de estrutura neurótica. Isso pode nos dar uma idéia, algo como: o autor considera que as estruturas neuróticas e psicóticas são em seu âmago diferentes, e que de tal diferença temos a conseqüência de que a técnica praticada na neurose não tem sentido, ou fracassa, nas psicoses. Ou seja, há uma diferença na psicanálise das neuroses e das psicoses. Sigamos à procura de tal diferença.

Para tanto, exploraremos o que os textos técnicos dessa época nos diz sobre a prática da psicanálise, pressupondo que ele fala essencialmente da neurose

Continuando a leitura do mesmo texto, o autor nos fala sobre essa técnica usada 'até o momento' no que diz respeito às neuroses. Faz-se importante compreendermos com prezo o que ele nos diz sobre a técnica em relação à neurose, para a partir dessa podermos pensar na psicose e nas suas implicações clínicas.

Então uma primeira pontuação de Freud pode ser lida:

Há muitas espécies de psicoterapia e muitos meios de praticá-la. Todos os que levam à meta da recuperação são bons. Nosso consolo corriqueiro, que tāo liberalmente dispensamos aos enfermos - "Você logo ficará bom de novo!" — , corresponde a um dos métodos psicoterapêuticos; mas agora que temos um discernimento mais profundo da natureza da neurose, não somos obrigados a ficar restritos a esse consolo. [grifo meu] Desenvolvemos a técnica da sugestão hipnótica, a psicoterapia através da 
distração, do exercício e da provocação de afetos mais oportunos. Não menosprezo nenhuma delas e utilizaria todas em condições apropriadas. Se realmente me restringi a um único procedimento terapêutico, ao método que Breuer chamou "catártico" [grifo do autor], mas que prefiro chamar de "analítico" [grifo do autor], foram apenas motivos subjetivos que me decidiram a fazê-lo. Em decorrência de minha participação na criação dessa terapia, sinto-me pessoalmente obrigado a me dedicar a explorá-la e a construir sua técnica. Posso asseverar que o método analítico de psicoterapia é o mais penetrante, o que chega mais longe, aquele pelo qual se consegue a transformação mais ampla do doente. Abandonando por um momento o ponto de vista terapêutico, posso acrescentar em favor desse método que ele é o mais interessante, o único que nos ensina algo sobre a gênese e a interação dos fenômenos patologicos. Graças ao discernimento do mecanismo das doenças anímicas que ele nos faculta somente ele deve ser capaz de ultrapassar a si mesmo e de nos apontar o caminho para outras formas de influência terapêutica. [grifo meu] (Freud, 1905, p. 243)

O que se pode extrair desse trecho é que, essencialmente, o método catártico e o método sugestivo diferem decisivamente. O autor diz que a partir do desenvolvimento e estudo dessa técnica, que ele prefere chamar de analítica, pode-se deixar de lado, e não se restringir a essas intervenções da técnica da sugestão hipnótica. Inclusive parece afirmar que em relação a essa técnica sugestiva, a analítica supera-a de várias formas, inclusive conseguindo trazer à tona algo sobre a gênese e a interação dos fenômenos patológicos.

Nesse texto, Freud dá um passo decisivo no caminho da psicanálise: abandona a hipnose em favor de uma outra forma de atuar. A partir daí é que a psicanálise enquanto técnica e método se funda com mais força. E no que diz respeito a nossa questão, a clínica, mais precisamente a das psicoses, essa prática analítica se diferencia em relação à hipnose. É algo muito distante da mesma.

Na sequiência, o autor começa a enumerar alguns esclarecimentos em relação a imagem pré-concebida que circula no meio médico sobre essa nova técnica. No primeiro ponto ele já nos define algo de primordial para a compreensão desta. Escreve:

(a) Observo que esse método é muito amiúde confundido com o tratamento hipnótico por sugestão; (...) Na verdade, há entre a técnica sugestiva e a analítica a maior antítese possivel, aquela que o grande Leonardo da Vinci resumiu, com relação às artes, nas fórmulas per via di porre [grifo do autor]e per via di levare [grifo do autor]. A pintura, diz Leonardo, trabalha per via di porre, pois deposita sobre a tela incolor partículas coloridas que antes não estavam ali; já a escultura, ao contrário, funciona per via di levare, pois retira da pedra tudo o que encobre a superfície da estátua nela contida. De maneira muito semelhante, senhores, a técnica da sugestão busca operar per via di porre; não se importa com a origem, a força e o sentido dos sintomas patológicos, mas antes deposita algo - a sugestão - que ela espera ser forte o bastante para impedir a expressão da idéia patogênica. A terapia analítica, em contrapartida, não pretende acrescentar nem introduzir nada de novo, mas antes tirar, trazer algo para fora, e para esse fim preocupa-se com a gênese dos sintomas patológicos e com a trama psíquica da idéia patogênica, cuja eliminação é sua meta. [grifo meu] Por esse caminho de 
investigação é que ela faz avançar tão significativamente nossos conhecimentos. Se abandonei tão cedo a técnica da sugestão, e com ela, a hipnose, foi porque nāo tinha esperança de tornar a sugestão tão forte e sólida quanto seria necessário para obter a cura permanente. Em todos os casos graves, vi a sugestão introduzida voltar a desmoronar, e então reaparecia a doença ou um substituto dela. Além disso, censuro essa técnica por ocultar de nós o entendimento do jogo de forças psíquico; ela não nos permite, por exemplo, identificar a resistência [grifo do autor]com que os doentes se aferram a sua doença, chegando em função disso a lutar contra sua própria recuperação; e é somente a resistência que nos possibilita compreender seu comportamento na vida. (Freud, 1905, p. 245)

Aqui reafirma-se com veemência a diferença entre as duas técnicas e define-se um pouco mais sobre a técnica analítica. A partir da metáfora trazida por 'da Vinci', diz que a terapia analítica pretende trazer algo para fora, e acrescenta que há uma importância essencial no fator da resistência, que é exatamente o que dificulta esse 'trazer para fora' quanto o que possibilita compreender o comportamento na vida. Inclusive essa mesma resistência é encoberta e ocultada na técnica sugestiva.

Por mais que estamos concebendo diferenças entre a clínica da psicose e da neurose, creio que podemos Ter como certo que mesmo nas psicoses esse princípio deve ser levado em conta. Não se pretende 'adicionar' nada para o psicótico, no sentido de 'sugerir' algo a esse sujeito. Mias ainda não temos certo o que de fato deve acontecer, per via de levare, com o psicótico.

Esses outros fatores são esclarecidos no decorrer do texto quando o autor nos diz: "Essa terapia baseia-se, pois, na concepção de que as representações inconscientes — ou melhor, a inconsciência de certos processos anímicos — são a causa imediata dos sintomas patológicos." (Freud, 1905, p.249)

Aquele 'trazer algo para fora' toma aqui sentido particular. É tornar consciente certos processos anímicos e representações antes inconscientes que seriam a causa imediata dos sintomas patológicos. Mais a frente continua:

$\mathrm{O}$ desvendamento e a tradução do inconsciente realizam-se sob uma resistência contínua por parte do enfermo. O afloramento desse inconsciente está vinculado ao desprazer, e é por causa desse desprazer que o doente o rejeita vez após outra. É nesse conflito na vida anímica do paciente que os senhores intervêm; se conseguirem levá-lo a aceitar, motivado por uma compreensão melhor, algo que até então rejeitara (recalcara) em consequiência dessa regulação automática do desprazer, terão realizado com ele parte de um trabalho educativo. (...) Portanto, de modo muito geral, os senhores podem conceber o tratamento psicanalítico como essa espécie de pós-educação para superar as resistências internas. Mas em nenhum ponto essa pós-educação é mais necessária, nos doentes nervosos, do que no tocante ao elemento anímico de sua vida sexual. É que em parte alguma a cultura e a educação causaram danos tão grandes quanto justamente aí, e é também aí, como thes mostrará a experiência, que se encontrarão as etiologias das neuroses passíveis de ser dominadas; quanto ao outro elemento etiológico, a contribuição constitucional, ele nos é dado como algo inalterável. [grifos do autor] (Freud, 1905, p. 250) 
A resistência aqui é colocada como parte decisiva do processo, pois o afloramento desse inconsciente está vinculado ao desprazer, em relação a esse o indivíduo então se defende resistindo. Acrescenta também que esse inconsciente é da ordem do sexual. A prática da psicanálise é compreendida como a superação dessas resistências internas e parece consistir nisso a 'cura' para essa teoria. Então compreende-se que a psicanálise da estrutura neurótica, a direção do tratamento, está intimamente ligada à resistência e ao inconsciente sexual.

Diante dessas valiosas colocações, a pergunta inicial fica um pouco mais clara. Ao se compreender melhor o que consiste essa técnica, pode-se desenvolver melhor o porque esta não é aplicável às psicoses. O caminho possivelmente é de procurar sobre esses processos e como se configuram nas psicoses, a saber: tornar consciente conteúdos inconscientes, a própria resistência, o próprio inconsciente, etc. Isso porque ficou-nos claro que a técnica se funda nessas questões.

Afinal, temos já um esboço de resposta para a questão da clínica das psicoses. Podemos vislumbrar o que não é. Na lógica da negação que o próprio texto freudiano nos coloca, é possível extrair que: todos esses processos descritos (inconsciente, resistência, etc....) são tão diferentes na psicóse que a técnica toda vai por água abaixo, não surte o mesmo efeito.

3) Estudo do texto "Sobre o Início do Tratamento (novas recomendações sobre a técnica da psicanálise I)".: do que diverge e do que converge na técnica.

Como diz o próprio título, esse texto pretende dar recomendações, regras e considerações sobre a fase inicial do tratamento, já que o autor compreende que esse é um momento decisivo no tocante ao tratamento como um todo.

É interessante abordarmos esse texto pois data da mesma época do texto anterior. Inclusive faz-se referência àquele como complementar no que concerne à técnica da psicanálise.

Dá-se bastante atenção a este experimento preliminar que seriam as primeiras entrevistas em psicanálise. Freud fala da importância destas para a possibilidade mínima de diagnóstico e para que o analista possa obter um mínimo de informação para localizar-se na questão que o paciente traz.

Há uma sequiência no que diz respeito ao conceito de 'resistência' entre esse texto e o anterior, o que nos reafirma a importância desta no tratamento das neuroses. Em uma nota de rodapé (Freud, 1913, p. 181) remetese ao texto "a dinâmica da transferência", quando trata dessa resistência, e 
talvez seja interessante estudar aquele texto no intuito de levantar o que ele pode dizer sobre a psicose.

No que diz respeito a nossa questão em relação às psicoses, o autor traz considerações importantes. Ainda tratando das entrevistas preliminares e sua importância o autor escreve:

Com bastante frequiência, quando se vê uma neurose com sintomas histéricos ou obsessivos, que não é excessivamente acentuada e não existe há muito tempo - isto é, exatamente o tipo de caso que se consideraria apropriado para tratamento - tem-se de levar em conta a possibilidade de que ela possa ser um estádio preliminar do que é conhecido por demência precoce ('esquizofrenia', na terminologia de Bleuler; 'parafrenia', como propus chamá-la) e que, mais cedo ou mais tarde, apresentará un quadro bem pronunciado dessa afeç̧ão. Não concordo que seja sempre possível fazer a distinção tão facilmente. [grifo meu] (Freud, 1913, p. 165)

Existiria uma diferença entre essas 'afecções': a neurose e a dita parafrenia que temos como a psicose que pesquisamos aqui. No entanto o autor deixa claro que nem sempre é possível fazer essa distinção tão facilmente. E principalmente, deixa a idéia de que isso tem implicações decisivas no tratamento. No caso de ser uma psicose em estádio preliminar, mais cedo ou mais tarde o quadro se mostrará com mais força.

Tudo isso toca-nos diretamente, pois é sobre essa diferenciação entre as duas estruturas, e somente assim, que poderemos concluir alguma coisa das questões que direcionam o presente trabalho. Compreender essa diferença é primordial.

Na continuação do texto o autor de certa forma reafirma o que dizia no texto anterior sobre as impossibilidades da técnica em relação à psicose, e acaba por introduzir algo de novo ao puxar uma nota de rodapé. Lê-se:

Ele [o analista] não pode cumprir sua promessa de cura se o paciente está sofrendo, não de histeria ou neurose obsessiva, mas de parafrenia, e, portanto, tem motivos particularmente fortes para evitar cometer equívocos no diagnóstico. Num tratamento experimental de algumas semanas, ele amiúde observará sinais suspeitos que possam determiná-lo a não levar além a tentativa. Infelizmente, não posso asseverar que uma tentativa deste tipo sempre nos capacite a chegar à decisão certa; trata-se apenas de uma sábia precaução a mais.

"Há muito a ser dito sobre a incerteza no diagnóstico, sobre as perspectivas de sucesso na análise de formas brandas da parafrenia e sobre as razões para a semelhança entre os 2 distúrbios, mas não posso estender-me sobre estes assuntos no presente contexto. Gostaria de acompanhar Jung no contrastar a histeria e a neurose obsessiva, como 'neuroses de transferência' [grifo meu], com as afecções parafrênicas, como 'neuroses de introversão' (da libido) [grifo meu] de seu único significado legítimo." (Freud, 1913, p. 166) 
Se o que ocupava-nos era a diferenciação entre neurose e psicose, aqui o autor nos dá direções. Há uma consideração sobre as psicoses que coloca duas noções a serem estudadas., a saber: introversão, e libido. Trata-se de noções que ele atribui de certa forma a Jung, mas que não perdemos em considerar seriamente tais colocações. Deixemos em suspenso essa diferenciação e continuemos nesse texto.

Os conceitos de transferência e resistência tomam cada vez mais importância no texto. E temos então esse trecho que esclarece um pouco mais sobre o papel desses no tratamento da neurose: "Só merece o último nome [tratamento analítico] se a intensidade da transferência foi utilizada para a superação das resistências [grifo meu]. Somente então a enfermidade tornou-se impossível, mesmo quando a transferência foi mais uma vez desfeita, o que é seu destino." (Freud, 1913, p.186/7)

A técnica psicanalítica para as neuroses serve-se da intensidade da transferência para conseguir superar as resistências. Temos, até agora e somando-se até aqui, um perfil bem mais claro sobre o que o autor caracterizava como técnica da psicanálise nessa época, que o levou a considerar que a mesma não seria aplicável às psicoses.

O que norteará mais fortemente o trabalho a partir daqui será a diferenciação entre psicoses e neuroses e as implicações da mesma diferenciação nas concepções de transferencia e resistência, para podermos compreender seus lugares na prática clínica com as psicoses.

4) Estudo do texto "Sobre o narcisismo: uma introdução".: características essenciais do investimento libidinal e conceituação de introversão nas estruturas clínicas.

A densidade e a quantidade de informação contidos neste texto freudiano são algumas características que fazem-nos tratá-lo com muito cuidado.

Aqui o autor irá tratar basicamente dos problemas relacionados aos conceitos de libido e de relação de objeto. Ainda levanta discussões acerca de colocações feitas por Jung e Adler. No que diz respeito ao presente trabalho, o autor coloca em pauta aquela divisão atribuída a Jung, que vínhamos estudando no capítulo anterior. Trata-se da diferenciação entre neurose e psicose e a maneira como Jung considerava essa diferença entendendo neuroses de transferência e neuroses de introversão (as psicoses). Sobre a proposta de Jung, Freud lançará algumas críticas que nos servirão bem ao nosso intuito. O autor escreve:

Um motivo premente para nos ocuparmos com a concepção de um narcisismo primário e normal surgiu quando se fez a tentativa de incluir o que conhecemos da demência precoce (Kraepelin) ou da esquizofrenia (Bleuler) na hipótese da teoria da libido. Esse tipo de pacientes, que eu propus fossem denominados de parafrênicos, exibem duas 
características fundamentais: megalomania e desvios de seu interesse do mundo externo - de pessoas e coisas. Em consequiência da segunda modificação, tornam-se inacessíveis à influência da psicanálise e não podem ser curados por nossos esforços. Mas o afastamento do parafrênico do mundo externo necessita ser mais precisamente caracterizado. Um paciente que sofre de histeria ou de neurose obsessiva, enquanto sua doença persiste, também desiste de sua relação com a realidade. Mas a análise demonstra que ele de modo algum corta suas relaçóes eróticas com as pessoas e as coisas. Ainda as retém na fantasia, isto é, ele substitui, por um lado, os objetos imaginários de sua memória por objetos reais, ou mistura os primeiros com os segundos, e, por outro, renuncia à iniciação das atividades motoras para a obtenção de seus objetivos relacionados àqueles objetos. Essa é a única condição da libido a que podemos legitimamente aplicar o termo 'introversão' da libido, empregado por Jung indiscriminadamente. Com o parafrênico a situação é diferente. Ele parece realmente ter retirado sua libido de pessoas e coisas do mundo externo, sem substituí-las por outras na fantasia. Quando realmente [grifo do autor] as substitui, o processo parece ser secundário e constituir parte de uma tentativa de recuperação, destinada a conduzir a libido de volta a objetos. (Freud, 1914, p.90)

O parágrafo é muito denso e de certa forma fácil de se perder a linha de raciocínio, o que nos pede uma analise pormenorizada.

$\mathrm{Na}$ primeira frase o autor coloca que a questão de fundo das discussões sobre o narcisismo estão e foram levantadas também pela tentativa de se compreender as psicoses através da teoria da libido. Nesse sentido, toca-nos diretamente.

Em seguida coloca duas características específicas dos pacientes psicóticos: megalomania e desvio do interesse em pessoas e coisas. Não fica claro aqui qual o caminho desse desvio, simplesmente há esse desvio do interesse. Assim, exatamente por não terem interesse em pessoas e coisas, o analista não está no campo das coisas que interessam-no. Logo, a conclusão que se chega é a de que a análise não consegue Ter influência nesses sujeitos. Formamos até agora a concepção de tratamento psicanalítico proporcionada através dos textos técnicos abordados inicialmente no presente trabalho. Ou seja: a tentativa de suspender a resistência e todas as outras características apresentadas no tratamento da neurose não funcionam na psicose, inclusive por que a influencia da transferência também se dá de forma diferenciada nas duas estruturas clínicas. E aqui o autor expõe por que essa transferência é diferente: exatamente por que o psicótico deixa de investir nas coisas externas, e a análise está nesse campo de coisas. Preferiria deixar quaisquer conclusões em suspenso por enquanto, até por ainda não sabermos direito como conceber o tratamento da psicose. Na verdade procuramos saber exatamente como seria possível pensar essa clínica.

No entanto, o autor coloca que ainda parece ser muito problemático compreender esse afastamento característico da esquizofrenia, e está atento ao fato de que a conceituação e compreensão precisa desse afastamento ainda é um trabalho a ser empreendido. 
Inclui que, no caso das neuroses, também há distanciamento da realidade; um neurótico também desiste da sua relação com as pessoas e as coisas. Essa colocação demonstra um pouco melhor a dificuldade, que já abordamos, de se delinear melhor uma coisa e outra (psicose e neurose).

Então, o autor escreve que o neurótico desiste da relação com as pessoas e as coisas reais, mas que as retém na fantasia. Isso significa que há uma confusão entre objetos reais e fantasiosos, mas que de qualquer forma, a consequiência disso é que de alguma forma o neurótico desiste da iniciativa de obter seu objetivos relacionados aos objetos. O complicado é que não sabemos onde Freud está falando de objetos reais ou se de objetos imaginários. Parece que desiste da relação com alguns objetos mas que restitui uma outra relação com um outro objeto, que dá uma impressão estranha de se tratar de um objeto tanto fantasioso quanto real. Mas o que está mais claro é que o neurótico também desiste da relação com objetos, mas não se para por aí: o neurótico substitui os objetos, já que desiste da relação com alguns objetos da realidade e não com a realidade como um todo.

Podemos também interpretar o que o autor escreve da seguinte forma: o neurótico, num momento, substitui os objetos imaginários de sua memória por objetos reais, e num outro momento, desiste da iniciativa de obter os objetivos relacionados àquele objeto primeiro, imaginário, que ao que tudo indica, fora perdido.

Nesse sentido, essa é a única configuração da relação objetal que pode ser chamada adequadamente de introversão da libido. Assim, aquela colocação de Jung vista no texto anterior, de certa forma não é mais válida. A diferença deve ser pautada em outro lugar, já que a neurose é que apresenta uma introversão da libido, enquanto que naquela passagem o autor colocava que essa introversão era o que caracterizava a psicose. Freud nos demonstra que não é por aí.

Vale a pena tentar reformular a partir destas colocações o que é essa introversão para que possamos compreender que o que acontece com a psicose é diferente.

Pode ser que estejamos nos repetindo, mas me parece ser válido.

Introversão seria: retirada do investimento na relação com alguns objetos através da substituição deste objeto por outros objetos tanto imaginários quanto reais, ou seja, desiste-se da relação de obtenção de algo referente a um objeto, mas não é uma desistência total, já que sobrevive no imaginário essa relação. Parece ser esse o mecanismo de introversão possível de ser compreendido a partir deste trecho do texto.

A grande diferença do psicótico reside no fato de que ele 'realmente' retira (e parece que totalmente) sua libido das pessoas e coisas do mundo externo, e não substitui por outras na fantasia. 
$\mathrm{Na}$ última frase desse parágrafo, o autor escreve que quando o psicótico consegue, de alguma forma, fazer essa substituição (e aqui Freud grifa o termo 'realmente', dizendo que é assim que o psicótico as substitui) esse processo parece ser parte de uma tentativa de reconduzir a libido aos objetos.

Até aqui, podemos supor 2 coisas:

- quando Freud escreve e grifa o 'realmente' ele pode estar dizendo que essa substituição ainda não é, e nunca vai ser, a substituição da neurose, que se dá na fantasia. A substituição é real e não sabemos direito o que o autor quer dizer com isso.

- Quando diz que é uma tentativa de reconduzir a libido aos objetos, puxa uma nota de rodapé que refere-se ao 'fim do mundo' na análise do caso Schreber. Podemos supor que ele diz aqui da construção delirante e sua função para a psicose. Ou seja: a função do delírio para a psicose seria tentar reconduzir a libido aos objetos.

Quanto ao delírio e sua função, fica algo em suspenso. Parece-nos que o autor demonstra (na verdade, escreve claramente) que esse delírio enquanto processo que tenta reconduzir a libido aos objetos, é um processo secundário. Isso nos dá a entender que há um processo primário na psicose, que inclusive parece dizer mais sobre a estrutura, e não enquanto sinais externos, ou consequiências desse processo primário. Abre-se uma questão, a de saber o que é isso que 'inaugura' uma estrutura psicótica, se é que Freud fala disso quando diz sobre algum processo anterior ao delírio. Sendo assim, é importante para o trabalho compreender o que seria esse processo anterior, e inclusive que possibilita o posterior delírio. Ficaria mais claro inclusive que postura, que caminho seguir diante da psicose, e mais especificamente diante do delírio, já que é disso que se trata o trabalho. No entanto já temos alguma possibiiidade de saber do que se trata. Se o delírio representa uma tentativa posterior em relação aos objetos, podemos supor, ou melhor, podemos direcionar a pesquisa para a seguinte questão: como se dá a relação com os objetos externos na psicose, já que o neurótico tem a possibilidade da fantasia? O que está acontecendo com o psicótico em relação às pessoas e coisas anteriormente ao delírio e sua irrupção? As leituras seguintes pretendem então trilhar esse fio de meada.

Mesmo sabendo que várias questões complexas ficam, por hora, sem resposta, continuaremos seguindo o texto.

$\mathrm{O}$ autor prossegue sua exposição tendo, como questão a ser explorada, o seguinte problema: o que acontece à libido que fora afastada dos objetos externos na esquizofrenia? É por causa desse problema que faz-se necessário um novo conceito que seria o narcisismo, o qual o autor pretende introduzir nesse texto.

Essa discussão se desenrola da seguinte forma: haveria um autoerotismo primordial para que só posteriormente o narcisismo fosse possível, e 
isso por um motivo muito simples, pois o autor considera que uma unidade comparável ao eu não pode existir no indivíduo desde o início de sua vida, o 'eu' deve ser desenvolvido. Assim, esse auto-erotismo seria primordial em relação ao narcisismo, de forma que para que tal narcisismo se constitua, seria necessário que algo de novo se adicionasse ao auto-erotismo.(p. 93)

Uma outra questão também se coloca: haveria uma diferenciação entre libido do ego e libido objetal. Mas por enquanto não vale a pena se aprofundar nessa diferenciação.

Numa dada passagem, o autor já nos fala, de certa forma, o destino dessa libido que o psicótico retira das pessoas e das coisas, e que não substitui estas na fantasia. Aqui, o que está em jogo é a crítica feita por Jung sobre uma insuficiência da teoria libidinal para explicar a perda de realidade característica da psicose. Temos:

Em sua grande obra seguinte, Jung (1913 [339-40]) simplesmente falha na solução que eu havia indicado: 'Ao mesmo tempo', escreve, 'ainda há o seguinte a ser levado em consideração (um ponto ao qual, incidentalmente, Freud se refere em sua obra sobre o caso Schreber [1911c]) - que a introversão da libido sexualis [grifo do autor] conduz a uma catexia do "ego", e que possivelmente é isso que produz o resultado de uma perda da realidade. É realmente uma possibilidade tentadora explicar a psicologia da perda da realidade dessa maneira'. Mas Jung não vai muito além no exame dessa possibilidade. Algumas linhas adiante ele a põe de lado com a observação de que essa determinante 'resultaria na psicologia de um anacoreta ascético, não em demência precoce'. Quão pouco essa analogia inadequada pode ajudar-nos a resolver a questão fica claro pela consideração de que um anacoreta dessa espécie, que 'tenta erradicar todos os traços de interesse sexual' (mas só no sentido popular da palavra 'sexual'), nem sequer necessariamente exibe qualquer localização patogênica da libido. Ele pode ter desviado inteiramente seu interesse sexual dos seres humanos; contudo, pode tê-lo sublimado num interesse elevado pelo divino, pela natureza, ou pelo reino animal, sem que sua libido tenha sofrido introversão até suas fantasias ou retorno a seu ego. [grifo meu] (Freud, 1914, p. 97)

$\mathrm{O}$ argumento freudiano contra a analogia do anacoreta ascético acaba nos falando um pouco sobre que destino a libido teria. $\mathrm{O}$ autor nos coloca que esse 'monge' pode Ter desviado sua libido das pessoas humanas, no entanto, pode Ter reinvestido essa libido num interesse elevado pelo divino, pela natureza ou pelo reino animal. Essas possibilidades, inclusive, Freud nos dá a idéia de que não são condições patológicas da libido. Então ele completa que esse anacoreta pode estar articulando sua libido dessas formas sem que necessariamente sua libido tenha sofrido introversão até suas fantasias ou retorno a seu ego.

Se já havíamos analisado que a introversão da libido, que é a substituição por objetos da fantasia, é uma característica das neuroses, podemos supor que com a palavra 'ou', nessa frase, o autor diferencia esse remanejo da libido (substituição), de um outro, retorno ao ego da mesma energia. Seria essa 
a condição da psicose? O retorno da libido ao ego. A libido objetal e a libido do ego se confundiriam, até mesmo por que a dita libido objetal reverteu-se para o ego, está fluindo para o ego. É de interesse investigarmos essas possibilidades. Num outro momento do texto, onde o autor ainda está melhor definindo esses conceitos, ele chama a atenção para algo que é-nos interessante pensar em relação à nossa problemática:

Nesse ponto, nossa curiosidade naturalmente perguntará por que esse represamento da libido no ego teria de ser experimentado como desagradável. (...) Aqui podemos até mesmo aventurar-nos a abordar a questão de saber o que torna absolutamente necessário para a nossa vida mental ultrapassar os limites do narcisismo e ligar a libido a objetos. A resposta decorrente de nossa linha de raciocínio mais uma vez seria a de que essa necessidade surge quando a catexia do ego com a libido excede certa quantidade. Um egoísmo forte constitui uma proteção contra o adoecer, mas, num último recurso, devemos começar a amar a fim de não adoecermos, e estamos destinados a cair doentes se, em consequiência da frustração, formos incapazes de amar. (...)

Reconhecemos nosso aparelho mental como sendo, acima de tudo, um dispositivo destinado a dominar as excitaçōes que de outra forma seriam sentidas como aflitivas ou teriam efeitos patogênicos. Sua elaboração na mente auxilia de forma marcante um escoamento das excitaçōes que são incapazes de descarga direta para fora, ou para as quais tal descarga é, no momento, indesejável. No primeiro caso, contudo, é indiferente que esse processo interno de elaboração seja efetuado em objetos reais ou imaginários. A diferença não surge senão depois - caso a transferência da libido para objetos irreais (introversão) tenha ocasionado seu represamento. Nos parafrênicos, a megalomania permite uma semelhante elaboração interna da libido que voltou ao ego; talvez apenas quando a megalomania falhe, o represamento da libido no ego se torne patogênico e inicie o processo de recuperação que nos dá a impressão de ser uma doença.

Tentarei aqui penetrar um pouco mais no mecanismo da parafrenia e reunirei os conceitos que já me pareçam merecedores de consideração. A diferença entre as afeç̧ões parafrênicas e as neuroses de transferência parecem-me estar na circunstância de que, nas primeiras, a libido liberada pela frustração não permanece ligada a objetos na fantasia, mas se retira para o ego. [grifo meu] A megalomania corresponderia, por conseguinte, ao domínio psíquico dessa última quantidade de libido, e seria assim a contrapartida da introversão para as fantasias que é encontrada nas neuroses de transferência; uma falha dessa função psíquica dá margem à hipocondria da parafrenia, e isso é homólogo à ansiedade das neuroses de transferência. Sabemos que essa ansiedade pode ser transformada por uma elaboração psíquica ulterior, isto é, por conversão, formação de reação ou construção de proteções (fobias). O processo correspondente nos parafrênicos consiste numa tentativa de restauração, à qual se devem as surpreendentes manifestações da doença. [grifo meu] De uma vez que a parafrenia com frequiência, se não geralmente, acarreta apenas um desligamento parcial [grifo do autor] da libido dos objetos, podemos distinguir três grupos de fenômenos no quadro clínico: (1) os que representam o que resta de um estado normal de neurose (fenômenos residuais); (2) os que representam o processo mórbido (afastamento da libido dos seus objetos e, além disso, megalomania, hipocondria, perturbações afetivas e todo tipo de regressão); (3) os que representam a restauração, nos quais a libido é mais uma vez ligada a objetos, como uma histeria (na demência precoce ou na parafrenia propriamente dita), ou como numa neurose obsessiva (na paranóia). Essa nova catexia libidinal difere da primária por partir de outro nível e sob outras condiçōes. (Freud, 1914, p. 101/3) 
Mais uma vez temos um trecho bastante denso. Cortar partes desse parágrafo comprometeria nossa compreensão. Separar as frases e analisar cada uma separadamente faria perder o sentido que o contexto dá. Teremos de ir frase por frase acompanhando a citação.

A questão que se abre para o autor é: por que esse represamento da libido é vivido como desagradável? De qualquer forma, o autor ressalta que não se trata simplesmente de uma experiência de desprazer. Ligar a libido a objetos, e assim sair dos limites do narcisismo, torna-se absolutamente necessário para o ser humano. E resta saber porque.

A possível explicação que o autor coloca é a de que haveria um nível excedente dessa catexia libidinal do ego. esse excedente não consegue manterse no aparelho mental e precisa ser descarregado, senão é vivido como desagradável.

Adiante ele coloca que um ego forte consegue manejar esse excedente, mas que se por alguma frustração ficarmos incapazes de amar (ligar a libido aos objetos), o destino é certamente cairmos doentes. Daqui fica como ponto em suspenso que frustração seria essa? Inclusive se há alguma característica fundamental desta frustração na psicose.

Na primeira frase do outro parágrafo, o autor delineia algumas funções do aparelho mental, e considera que, em relação a esse excedente libidinal, é necessário que esse aparelho consiga dominá-lo, para que não hajam efeitos patogênicos. Segue-se outra frase onde é descrita duas situações em que o aparelho mental consegue agir: o aparelho mental auxilia no escoamento das excitações incapazes de uma descarga direta para fora, ou auxilia de alguma forma nas situações onde essa descarga é momentaneamente indesejável. Então coloca-se que no caso de viabilizar uma descarga, tanto faz se os objetos os quais a libido se ligará são reais ou imaginários. No entanto, se esses objetos forem irreais o que acontece é o represamento da libido no aparelho, o que ocasiona as condições patológicas. Abre-se no texto um parênteses e escreve-se 'introversão'. Dessa forma temos que na neurose, em situações patológicas, os objetos nos quais o investimento libidinal é feito, são irreais. Como já havíamos analisado em outro momento no início do texto, há essa substituição, mas os objetos poderiam ser tanto imaginários quanto irreais? Tínhamos que na neurose substitui-se as pessoas e as coisas na fantasia. Pode o autor estar dizendo que se esse objeto da fantasia for também real isso não terá efeitos desagradáveis para o aparelho mental, enquanto que se essa substituição se der em objetos irreais há então represamento? De qualquer forma, sabemos ao menos que quando o autor refere-se à introversão da libido, trata-se de um processo da neurose e não da psicose. E trata-se de objetos irreais, só não sabemos se isso aplica-se tanto às neuroses quanto às psicoses. 
Faz-se então o contraponto com a psicose. O autor nos expõe que, na psicose, a megalomania é que consiste numa elaboração dessa libido que voltou ao ego, ou seja, não possibilita o represamento, mas sim dá caminho para que o excedente libidinal escoe. Isso nos parece bem importante. Assim, somente quando houvesse uma falha nesse mecanismo (o manejo que a psicose faz da libido), a libido ficaria presa e então dá-se inicio a um processo de recuperação que parece de fora uma doença. Pode-se dizer que de certa forma sequer há investimento em objetos irreais ou reais ou quaisquer outros. Há sim uma falha da megalomania em sua função de elaboração da libido, conseqüente represamento da libido, e posteriormente o delírio apareceria enquanto tentativa de recuperação.

Isso tudo nos interessa deveras! Se procuramos saber qual a direção possível para uma clínica, para uma escuta da psicose, aqui temos dados para tirar alguma conclusão. Supomos que o delírio, a constituição deste, é que representa esse processo que parece uma doença e que tem por função tentar levar de volta a libido aos objetos, como já abordamos aqui. É possível imaginar então que, de alguma forma, em revelia à clínica da neurose (que tem por princípio levantar o recalque, que seria o que impossibilita esse escoamento da libido), na psicose, a constituição do delírio tem função primordial. $\mathrm{O}$ autor nos coloca que a megalomania tem essa função de manejo do excedente libidinal, ou seja, diante desta, ficaríamos impassível. No entanto, se o dito processo que nos dá a idéia de que uma doença já tivera iniciado, talvez o caminho a percorrer é de alguma forma, não sabemos como, viabilizar que esse delírio se constitua para que a libido escoe. É inclusive estranho pensar que a megalomania da psicose não consistiria numa manifestação do narcisismo! Já que de alguma forma dá conta do escoamento da libido, enquanto este narcisismo está sendo compreendido como não investimento da libido em pessoas e coisas. Ou haveriam outros tipos de narcisismo?

Há aqui uma questão de fundo que faz-se de primeira importância. Talvez ficasse melhor expresso como questão de chão, de fundamento, de princípio. O que está em jogo é o que a psicanálise tem como compreensão de saúde. Como a psicanálise concebe o saudável, já que alguma direção deve ser dada na clínica, e que sabemos que essa direção deve, sem dúvida nenhuma, estar pautada no que o sujeito nos traz. Ou seja, a direção quem dá é o paciente. Vislumbra-se aqui como trata-se de uma questão complexa. E que não podemos perder de vista. Até por que todo o presente trabalho só tem sentido se estivermos de acordo que o objetivo é procurar alguma possibilidade de 'cura' para o sofrimento do psicótico. O que ainda não nos é claro é como a psicanálise concebe essa cura, que parâmetros ela tem para compreender essa cura em nome do paciente, já que também não pode-se dar de antemão para o paciente o que é o melhor para ele. Sabemos que isso somente ele pode saber. 
- A questão é: como fazer ele saber. Bem, não cabe aqui, nesse momento, estender mais esse assunto. Deixemos em suspenso por enquanto.

Continuemos lendo o parágrafo que se segue. O autor dá continuidade ao raciocínio que havíamos iniciado com ele. Afirma então que a diferença da psicose reside no fato de que a energia desprendida na frustração (que na neurose pode ocasionar a introversão) não permanece ligada a objetos da fantasia, mas se retira para o ego. Dessa forma, a megalomania é o correspondente na psicose do mecanismo da introversão na neurose. Não tratase ainda de processos patológicos, o autor parece estar descrevendo processos das duas estruturas que dão conta do excedente libidinal. São mecanismos homólogos, e sendo assim, uma falha na função da megalomania dá margem à hipocondria característica da psicose, sendo isso o correspondente da ansiedade nas neuroses, como falha da substituição na fantasia dos objetos da realidade. Sistematizando um pouco: a megalomania da psicose enquanto função plena, sem falha que represe a libido, é homóloga à introversão para as fantasias na neurose, da mesma forma, enquanto conseguir elaborar a libido. A partir da falha nessas funções teríamos respectivamente a hipocondria nas psicoses e a ansiedade nas neuroses. Então, o que mais nos importa, essa ansiedade da neurose pode sofrer uma elaboração ulterior, e ser convertida numa formação de reação ou numa fobia, e isso é análogo à tentativa de restauração empreendida na psicose (que supomos no delírio e sua constituição, mas que no entanto parece tratar-se de algo muito mais geral).

$\mathrm{O}$ autor considera que desses vários tipos de tentativas de restauração (que representariam um desligamento parcial da libido) enumera algumas possibilidades na parafrenia. Na terceira descrição parece que ele trata daquilo que estamos supondo consistir o delírio, e escreve que nesse tipo de 'saída' há uma restauração, onde a libido é mais uma vez ligada aos objetos. Se supomos, no início do trabalho, que o delírio é característico de um quadro de paranóia (dado o caso Schreber, por exemplo), o autor ainda coloca que isso é homologo à 'saída' da neurose obsessiva. E acrescenta que essa nova possibilidade difere da catexia primária, como já vínhamos analisando.

Até aqui, também podemos tirar a conclusão clara de que, para Freud, a psicose em si não consiste numa patologia. $\mathrm{O}$ autor nos coloca claramente que a megalomania é um processo saudável nas psicoses, já que é o mecanismo que dá conta do excedente libidinal. O problema aparece quando, por algum motivo, esse excedente libidinal não consegue escoar. E então a psicose traz manifestações de um processo que tenta levar a libido de volta aos objetos. Há um salto de posição tomada pelo terapeuta diante da psicose. Não se trata de uma noção patologisante. Ao menos é isso que leio no texto freudiano. Isso tudo relaciona-se diretamente com aquela 'questão de fundo' levantada há 
pouco. E teremos talvez de separar um outro momento para tratarmos especificamente dessa questão.

Mais adiante no texto, o autor nos traz mais algumas contribuiçōes:

Não nos surpreenderíamos se encontrássemos um agente psíquico especial que realizasse a tarefa de assegurar a satisfação narcisista proveniente do ideal do ego, e que, com essa finalidade em vista, observasse constantemente o ego real, medindo-o por aquele ideal. (...) $O$ reconhecimento desse agente nos permite compreender os chamados 'delírios de sermos notados' ou, mais corretamente, de sermos vigiados, que constituem sintomas tão marcantes nas doenças paranóides, podendo também ocorrer como uma forma isolada de doença, ou intercalados numa neurose de transferência. [grifo meu] Pacientes desse tipo queixam-se de que todos os seus pensamentos são conhecidos e suas ações vigiadas e supervisionadas; eles são informados sobre o funcionamento desse agente por vozes que caracteristicamente lhes falam na terceira pessoa ('Agora ela está pensando nisso de novo', 'Agora ele está saindo'). Essa queixa é justificada; ela descreve a verdade. Um poder dessa espécie, que vigia, que descobre e que critica todas as nossas intençōes, existe realmente. Na realidade, existe em cada um de nós em nossa vida normal. (Freud, 1914, p. 112/113)

Aqui o autor nos fala que haveria um agente psíquico especial, que tem por função assegurar a satisfação proveniente do dito 'ideal do ego'. Essa satisfação é considerada essencialmente narcísica. Isso tem importância se considerarmos o que há pouco o texto nos trouxe: que é necessário para o ser humano a saída do narcisismo. Ainda descreve que a função desse agente da censura também seria a de observar constantemente o ego real, e medi-lo a partir daquele ideal. Então, Freud introduz a questão dos 'delírios de sermos vigiados', considerando estes como manifestação daquele agente específico de vigilância na paranóia. A queixa trazida por esses pacientes falam que seus pensamentos são conhecidos e tudo que se passa em sua mente é constantemente vigiado. Isso tudo ocorre na mente do psicótico e ele ouve as vozes, em terceira pessoa, dizendo-lhe o que esse agente sabe sobre sua vida mental. O autor reconhece aqui uma manifestação da instância psíquica que vigia e regula o funcionamento do ego: sabemos tratar-se do superego. Completa dizendo que existe em cada um de nós, na vida mental normal. Dessa forma, compreende-se que a manifestação do superego na psicose se dá de forma diferenciada da neurose. Esse agente não é atribuído a si mesmo, mas ao mundo externo. Algo acontece com a psicose que o indivíduo não reconhece essa instância como interna. No entanto, de alguma forma, o psicótico 'carrega' (se é que faz sentido dizer isso) essa instância, o que nos permite dizer que ao menos algo aconteceu com ele para que esse ideal do ego, e o superego enquanto veículo desse ideal, tenha feito algum registro na vida mental desse sujeito. Não sabemos por que esse registro do 'ideal' se dá de forma tal que o 
sujeito não atribui este a si mesmo, mas ao mundo externo. Mas, continuemos a leitura.

Os delírios de estar sendo vigiado apresentam esse poder numa forma regressiva, revelando assim sua gênese e a razāo por que o paciente fica revoltado contra ele, pois o que induziu o indivíduo a formar um ideal do ego, em nome do qual sua consciência atua como vigia, surgiu da influência crítica de seus pais (transmitida a ele por intermédio da voz), aos quais vieram juntar-se, à medida que o tempo passou, aqueles que o educaram e lhe ensinaram, a inumerável e indefinivel coorte de todas as outras pessoas de seu ambiente - seus semelhantes - e a opiniāo pública. [grifo meu] (Freud, 1914, p.113)

Caracteriza-se esse 'poder' de vigilância na psicose como regressivo, e não sabemos direito o que Freud quer dizer com isso. Diz-se então sobre a revolta contra esse agente, e sua gênese: a formação do 'ideal do ego', e sua conseqüente função de vigia, surge da influencia crítica dos pais, transmitida por intermédio da voz. Isso parece-nos de alguma importância, pois se essa instância é transmitida por intermédio da voz (externa por excelência), por que é que na psicose ela continua atribuída ao mundo externo, enquanto que a neurose toma essa voz para si? Continuemos a leitura:

Dessa forma, grandes quantidades de libido de natureza essencialmente homossexual são introduzidas na formação do ideal do ego narcisista, encontrando assim um escoadouro e satisfação em conservá-lo. A instituição da consciência foi, no fundo, uma personificação, primeiro da crítica dos pais, e, subseqüentemente, da sociedade processo que se repete quando uma tendência à repressão se desenvolve de uma proibição ou obstáculo que proveio, no primeiro caso, de fora. As vozes, bem como a multidão indefinida, são reconduzidas ao primeiro plano pela doença, e assim a evolução da consciência se reproduz de forma regressiva. Mas a revolta contra esse agente de censura' brota não só do desejo, por parte do indivíduo (de acordo com o caráter fundamental de sua doença), de libertar-se de todas essas influências, a começar pela dos pais, mas também do fato de retirar sua libido homossexual delas. [grifo meu] A consciência do paciente então se confronta com ele de maneira regressiva, como sendo uma influência hostil vinda de fora.

As queixas feitas pelos paranóicos também revelam que, no fundo, a autocrítica da consciência coincide com a auto-observação na qual ela se baseia. Assim, a atividade da mente que assumiu a função da consciência também se coloca a serviço da pesquisa interna, que proporciona à filosofia o material para as suas operaçōes intelectuais. Isso pode ter certa relação com a tendência, característica dos paranóicos, de formar sistemas especulativos. (Freud, 1914, p.113/4)

O que está envolvido na formação desse ideal do ego é então grandes quantidades de libido homossexual, e isso parece ser um dado novo. Sabíamos até agora do caráter narcísico da formação do superego. No entanto, essa inclusão de uma nova variável não é claramente explicada nesse momento do texto. Até valeria a pergunta: essa libido homossexual não é narcísica? 
Esse ideal do ego é compreendido como narcisista, e inclusive, com o investimento de libido homossexual tem-se satisfação em conservar essa instância. Há então uma personificação da crítica dos pais, e parece-nos que o que acontece no psicótico é algo que exatamente despersonifica essa instância. Coloca-se que todo esse processo se repete na medida em que uma proibição ou obstáculo faz uma tendência a repressão, da libido, provavelmente. Pode-se inferir então que exatamente quando há um obstáculo que provoca a repressão da libido é que essa instância reaparece, agora no mundo externo, ouvido como voz exterior, na psicose. O autor escreve que a evolução da consciência se dá de forma regressiva, e já havíamos nos atentado para o uso deste termo. Então ele continua: a revolta contra esse agente de censura, que inferimos ser exatamente o processo que atribui ele ao mundo externo, acontece tanto pela parte do desejo do indivíduo de libertar-se dessas influências, quanto do fato de retirar sua libido homossexual dessas influências. Parece ser nesse sentido que o sentido de regressivo que o autor se refere. Resta saber se retirar a libido homossexual não afeta o investimento narcísico nesse ideal. Podemos compreender que, se na neurose o sujeito atribui a si mesmo o agente de censura, pode ser exatamente por que não há a necessidade de se retirar o investimento homossexual, nem o narcísico, do ideal. Parece mesmo que todo o processo da neurose não coloca, em primeiro tempo, essas instâncias em questão, como nos parece acontecer com a psicose. Já nesta estrutura, há uma revolta e esse investimento homossexual tende a ser desfeito, e é nesse sentido que compreendo o 'regressivo' usado pelo autor: como retirada (regresso) da libido homossexual. Enquanto um (neurose) investe homossexualmente no ideal, o psicótico, a partir de algum registro que ele já tenha dessa instância, passa a retirar o investimento homossexual daí. Não sabemos o que acontece com o caráter narcísico desse investimento. É então que a consciência do psicótico se confronta com essa instância, atribuindo esta a uma influência hostil vinda de fora.

O que complica toda a compreensão desse processo é o que está determinando esses caminhos diferentes na psicose e na neurose. Trata-se da grande questão, ao que parece. A partir dessas constatações do processo característico da psicose, por que é que a dinâmica mental dos investimentos toma essa direção, e não a da neurose. E não podemos 'cair em petição de princípio', respondendo redundantemente que é assim por que é psicose, sendo que a resposta sobre o que é psicose recai em: por que é assim que o processo se dá. Trata-se de um direcionamento importante para o presente trabalho, até para que essa diferenciação fique bem clarificada. $O$ que determina essa 'posição' da psicose diante desse agente, essencialmente ligado a influência crítica dos pais experienciada na infância da criança? 
Na continuação do trecho que estamos lendo, adiciona-se o fato de que a autocrítica da consciência coincide com a auto observação na qual ele se baseia. Explica o autor que a atividade de observação da mente, arraigada intimamente com a aquisição daquela instância que o psicótico deixa de investir homossexualmente, também se coloca a serviço da pesquisa interna. Isso parece ser algo característico das psicoses, pois ainda nos coloca o autor que essa pesquisa interna pode Ter relação com a tendência dos paranóicos de formar sistemas especulativos. Parece que a saída encontrada pelo psicótico desse conflito com a instância seria: deixar de investir homossexualmente (o que nos remete a um outro tipo de investimento que não sabemos do que se trata, mas supomos ser a continuidade do investimento narcísico nesse agente) naquela aquisição da influência crítica dos pais, e a partir desse novo investimento, outra função é dada a essa instância, ao invés de consistir num obstáculo ao investimento nas pessoas e coisas, passa a ser exatamente a instância que permite a formação de sistemas especulativos (que o autor compara com o trabalho da filosofia). Sendo assim, se nossa suposição estiver correta, o efeito de se retirar um investimento homossexual e manter um investimento narcísico em relação a essa instância censora, seria, em parte, o efeito da criação especulativa na construção delirante.

Esses sistemas especulativos da psicose é o que estamos chamando de delírio. Não podemos perder de vista que, além disso, estávamos abordando o delírio como tentativa de reinvestir nos objetos externos, ou seja, a partir de alguma impossibilidade de se investir nas pessoas e coisas, o psicótico cria o delírio na tentativa de retornar a libido a esses objetos. Parece haver uma incoerência. Como poderia uma condição narcísica ser uma tentativa de reinvestir nos objetos?

Isso nos leva a rever, por um momento, o caminho seguido até agora para que se levante uma questão:

Abordávamos que a megalomania é o mecanismo pelo qual a psicose consegue fazer a manutenção do excedente libidinal. Havia então uma divisão entre auto-erotismo e narcisismo, onde o primeiro é o excedente por excelência, enquanto o segundo seria uma aquisição posterior, já que é direcionada ao 'eu', e esse só pode ser concebido muito posteriormente na vida mental. Então, quando há uma falha nesse mecanismo da megalomania, temos a hipocondria como manifestação do represamento patológico da libido. É somente a partir daí que o delírio aparece, como tentativa de levar a libido de volta aos objetos, ou seja, saindo-se do narcisismo. Por mais que podemos supor que não existe completa saída do narcisismo, dada a colocação de que a própria tentativa de reinvestir (a construção delirante) envolva algum narcisismo (lembremos da passagem em que Freud nos diz sobre a necessidade de amar, e também da necessidade de amar a si próprio). Temos uma questão: será que, por algum 
momento anterior a essa situação, o psicótico investiu em objetos? Se sim, deve haver alguma peculiaridade do investimento objetal do psicótico que tenha como conseqüência as manifestações presentes nessa estrutura. Se não, temos de verificar o que houve, em tempos muito primordiais, que causou esta condição, em que a possibilidade de investimento objetal é somente secundária e posterior.

Além disso, o que é que provoca uma falha no funcionamento do mecanismo que faz a manutenção do excedente libidinal? Será que os fatores envolvidos são os mesmos na neurose e na psicose? Freud nos fala de obstáculos à satisfação, mas não sabemos que coisas conseguem Ter esse estatuto nas duas estruturas clínicas.

Temos ainda uma outra consideração: a libido homossexual, inerente a formação do ideal do ego, na situação que impede a satisfação (compreendida aqui de forma geral) na psicose, deixa de ser investida no ideal. Pressupondo-se que o narcísico e o homossexual são coisas diferentes. Então pode-se supor que essa libido homossexual retorne ao ego. Por um momento parece até uma inversão. Dá-se a entender que na condição da construção delirante, o investimento narcísico está no agente censor, enquanto que o investimento homossexual supostamente retornaria ao ego, e isso nos dá a impressão de ser o avesso da neurose. A criação delirante seria uma manifestação tanto da libido homossexual retornando ao ego, quanto do investimento narcísico no caráter de auto observação da instância censora, que proporcionaria o material para a criação especulativa.

Algo mais sobre o narcisismo é encontrado ao final do texto, onde coloca-se:

Uma parte da auto-estima é primária - o resíduo do narcisismo infantil; outra parte decorre da onipotência que é corroborada pela experiência (a realização do ideal do ego), enquanto uma terceira parte provém da satisfação da libido-objetal.

$O$ ideal do ego impõe severas condições à satisfação da libido por meio de objetos, pois ele faz com que alguns deles sejam rejeitados por seu censor como sendo incompativeis. [grifo meu] Onde não se formou tal ideal, a tendência sexual em questão aparece inalterada na personalidade sob a forma de uma perversão. Tornar a ser seu próprio ideal, como na infância, no que diz respeito às tendências sexuais nāo menos do que às outras - isso é o que as pessoas se esforçam por atingir como sendo sua felicidade. (Freud, 1914, p. 118)

Começa-se a exposição separando tipos de narcisismo: um primário que seria resíduo de um narcisismo infantil (se pensarmos que o 'eu' não é dado, podemos supor que o 'eu' tem certa evolução na vida mental, então podese supor que é um 'eu' primário que atua esse narcisismo); um outro narcisismo é decorrente da onipotência inerente a realização do ideal do ego (tornar o 'eu' como igual ao ideal, ou seja, tornar o 'eu' igual a imagem que se tem dos pais); 
haveria uma terceira modalidade, decorrente da satisfação da libido objetal. Isso significa que a perda de investimento objetal implica necessariamente num nível de perda narcísica.

Aquela frustração nos investimentos em objetos (pessoas e coisas) pode estar sendo entendida, a partir daqui, como imposições de condições superegóicas à satisfação da libido. O superego faz com que haja a rejeição de alguns objetos, pois esses são considerados incompatíveis pelo censor (uma das funções do superego). E, por conseguinte, há uma implicação no narcisismo de terceiro tipo, descrito acima. Assim, se a psicose se depara com essa impossibilidade de investir em objetos, poderíamos estar considerando que essa desistência é ocasionada por uma exigência do superego? No entanto já vínhamos abordando a possibilidade de haver uma implicação muito mais fundamental na inauguração dos investimentos objetais, e que talvez, para a psicose essa possibilidade só seja posterior. Então, o papel do superego na neurose enquanto aquele que impõe restrições à satisfação, e que essa impossibilidade de investimento em objetos, e sua conseqüente substituição na fantasia, deve ser considerado de forma diferenciada na psicose. Não sabemos se é o superego que impõe restrições ao investimento objetal ou se trata-se de uma impossibilidade mais fundamental, de forma que não podemos dizer que sejam essas restrições superegóicas que causem a falha do manejo do excedente libidinal, desempenhado na psicose pela megalomania. Sequer sabemos se há a possibilidade de conceber aqueles três níveis de narcisismo na psicose, se são iguais aos da neurose, se há aquele terceiro estágio do narcisismo implicado na satisfação da libido objetal. Se concebemos que na psicose a noção de investimento objetal deve ser colocada entre parênteses para uma análise pormenorizada, o narcisismo consequentemente é colocado em questão também. De fato não sabemos o que insere o sujeito psicótico nessa dificuldade que represa a libido, manifestada na hipocondria, e posterior tentativa de investimento nas pessoas e coisas, através da construção delirante.

$\mathrm{E}$ finalmente nas últimas frases do texto temos:

Originalmente esse sentimento de culpa era o temor de punição pelos pais, ou, mais corretamente, o medo de perder o seu amor; mais tarde, os pais são substituídos por um número indefinido de pessoas. A freqüente causação da paranóia por um dano ao ego, por uma frustração da satisfação dentro da esfera do ideal do ego, é tornada assim mais inteligível, bem como a convergência da formação do ideal e da sublimação no ideal do ego, e ainda a involução das sublimaçōes e a possível transformação de ideais em perturbações parafrênicas. (Freud, 1914,p. 119)

Sabemos que na psicose há uma 'revolta' contra essa instância de censura da vida mental. O resultado disso é o não reconhecimento da 'voz' da censura e conseqüente atribuição desta ao mundo externo. Isso nos leva a perguntar se o que é vivido pelo psicótico é algo da ordem da culpa, e parece- 
nos que não. $\mathrm{O}$ autor coloca que o sentimento de culpa é originalmente o temor de punição pelos pais, ou mais exatamente o medo de perder seu amor. Analisando as implicações da suposição de que algo mais primordial acontece com a objetalidade do psicótico, é interessante questionar se a vivência do psicótico em relação aos pais é de medo de perda do amor, e se não, do que se trata?

É claramente colocado que a causação da paranóia se dá por um dano ao ego, e frustração da satisfação na esfera do ideal do ego. Mas de fato não fica tão mais inteligível a transformação de ideais em perturbações parafrênicas.

Ainda não fica claro que processo primordial acontece para que essa internalização dos pais se dê nos moldes da neurose (que diante da impossibilidade imposta pelo superego de investir em objetos, substitui-os na fantasia), e por outro lado, na suposição da psicose (a partir da mesma impossibilidade, imposta pela mesma instância, provoca o desinvestimento total dos objetos e conseqüente investimento no ego e também o processo que atribui a instância superegóica ao mundo externo)

\section{Conclusão}

Levantaram-se vários pontos importantes no decorrer do trabalho. Dentre eles temos uma primeira consideração que é determinante de todas as outras conclusões subsequentes: a técnica psicanalítica para a neurose é inviável para a psicose. Uma das conseqüências diretas dessa afirmativa está na importância que o diagnóstico implica. Torna-se decisivo para a direção do tratamento que o analista saiba o bastante das estruturas clínicas para que possa reconhecê-las na medida em que o indivíduo procura a análise. E não só da importância, também deve-se considerar a dificuldade inerente a algumas situações onde a diferenciação entre neurose e psicose é, para o analista, muito sutil. Pode-se afirmar que somente com o material desse presente trabalho, não se tem as condições necessárias para empreender uma clínica da psicose, quanto mais da construção delirante. Tem-se esboços de direção, e só.

Abordava-se de inicio a fala da senhora E., é válido que considere-se a hipótese de uma psicose. No entanto o presente trabalho não esteve direcionado ao diagnóstico em si, o que nos faz Ter o cuidado de não fechá-lo. Dizer que trata-se de uma psicose somente pelos fenômenos observáveis naquela situação descrita consiste numa posição que tem seus efeitos. No caso de um 'erro' de diagnóstico (sendo uma neurose enquanto o diagnóstico é de psicose), o andamento do tratamento ou não terá efeitos ou será catastrófico. Isso esteve bastante claro na medida em que abordava-se o texto freudiano. Resumindo o 
que se pode concluir desse ponto: o diagnóstico implica na direção do tratamento e, logo, é decisivo no processo de cura.

De forma sumária pode-se dizer algo sobre a técnica para as neuroses, e então sabe-se o que não é a técnica usada no caso de uma psicose. É tornar consciente certos processos anímicos e representações antes inconscientes, que seriam a causa imediata dos sintomas patológicos; é nisso basicamente que consiste o tratamento para as neuroses.

Depois de abordar as considerações freudianas sobre a divisão proposta por Jung (em 'neuroses de transferência' para as neuroses, e 'neuroses de introversão' para as psicoses), inclusive de considerar as insuficiências dessa divisão conceitual, pode-se eleger alguns pontos importantes sobre a diferenciação entre essas duas estruturas.

As duas estruturas desistem do investimento em pessoas e coisas quando numa condição patológica, e é somente nisso que são semelhantes. O neurótico substitui os objetos da realidade (pessoas e coisas) por objetos da fantasia. Assim, se por um lado desiste do investimento, do outro os mantém na fantasia. No entanto, numa situação patológica, esse mecanismo, por algum motivo, não dá conta do excedente libidinal.

A psicose não desfruta desse processo de substituição na fantasia. $\mathrm{Na}$ verdade não sabemos direito sobre a natureza do mecanismo que, nessa estrutura, consegue fazer a manutenção do excedente libidinal. Quando o psicótico desiste do investimento nas pessoas e coisas ele não as substitui na fantasia, e não sabemos por quê.

Ao menos pôde-se verificar que a construção delirante é um processo secundário, consiste numa tentativa de reinvestir nos objetos da realidade (pessoas e coisas). Ou seja, é um processo posterior a uma falha num outro mecanismo, e consiste na tentativa de 'arrumar' essa falha. Se na neurose aquela substituição na fantasia era o que dava conta do excedente libidinal, tem-se que na psicose a megalomania admite esse papel. É quando esse processo por algum motivo falha que inicia-se o processo secundário que considerou-se aqui como delírio.

Existem duas implicações desses fatos. Uma delas é que o conceito de patologia, para a psicanálise, está intimamente ligada ao represamento do excedente libidinal. Outra, é que a estrutura psicótica em si não é exatamente uma patologia, pois consegue dar conta do excedente libidinal. E isso tem importância vital na clínica, pois nos diz que quando diante de uma manifestação dessa megalomania "saudável" não deve-se sequer tentar modificá-la. E quando diante de uma construção delirante, a direção seria viabilizar, de alguma forma que não sabemos como, que essa construção se estabilize, pois ela consiste numa tentativa de reinvestir nos objetos, e assim evitar o represamento da libido. 
Mas tenhamos cuidado! Creio que a conceituação de patologia para a psicanálise não seja tão simples assim. Não tem-se até então subsídios para definir claramente o que é uma coisa e o que é outra (por exemplo: a megalomania que dá conta do excedente e uma manifestação secundária da patologia, ou a patologia em si). Definitivamente tem-se pouco para tentar fechar uma técnica. Não chegou o presente trabalho na conclusão de como viabilizar esse processo secundário que é o delírio. E tem-se somente um aspecto da patologia, que é esse dos investimentos libidinais, no entanto não é o único aspecto a ser considerado. Da mesma forma que não há condições de fechar um diagnóstico, por não Ter subsídios nesse momento da pesquisa, não se pode concluir sobre o que é a patologia, e qual a direção exata para cada caso. Precisa-se considerar o que a pesquisa nos trouxe, e inclusive pensar nas implicações clínicas do que a pesquisa produziu. Pode-se a partir daqui dar direcionamentos possíveis para que esse saber torne-se mais conciso.

Algumas diferenças também podem ser vistas no que diz respeito à instância mental que tem por função censurar (superego), e as suas relações com a vida mental numa e noutra estrutura. A estrutura neurótica investe narcísica e homossexualmente no ideal do ego, que está relacionado ao superego. Já na psicose o investimento homossexual é retirado do ideal do ego, e o investimento narcísico parece ser exatamente o que fornece material para que o processo de construção do delírio se dê. O investimento narcísico na instância censora irá focalizar as energias na função observadora da vida mental. Dá-se a entender que na condição da construção delirante, o investimento narcísico está no agente censor, enquanto que o investimento homossexual supostamente retornaria ao ego, e isso nos dá a impressão de ser o avesso da neurose. A criação delirante seria uma manifestação tanto da libido homossexual retornando ao ego, quanto do investimento narcísico no caráter de auto observação da instância censora, que proporcionaria o material para a criação especulativa.

Uma direção possível para a pesquisa seria abordar o texto lacaniano sobre as psicoses (seminário 3 - as psicoses, 1955), pois deve-se considerar que a partir daqui, tem-se mais subsídios para poder aproveitar o que esse texto tem a nos dizer. Inclusive para direcionar a pergunta que ficou em aberto nesse trabalho. A questão é: que tipo de relação é essa que o psicótico empreende com os objetos? Como inaugurou-se essa possibilidade de relação? De certa forma seria poder saber mais sobre a estrutura psicótica em si.

Outro texto que pode ser visto, principalmente para se tecer considerações técnicas sobre o delírio, seria o texto freudiano intitulado 'construções em análise'. Nesse texto pode-se encontrar pontos importantes a esse respeito. $\mathrm{O}$ autor faz um paralelo entre as construções empreendidas pelo analista em seu trabalho de análise, e seus efeitos 'terapêuticos' dessas 
construções na clínica da neurose, e a construção delirante, considerando o que ele chama de 'fragmento de verdade histórica'. Isso pode nos dar indicações muito importantes sobre o quê seria essa possibilidade que levantou-se no presente trabalho: a viabilização do delírio na psicose.

\section{Referências Bibliográficas}

FREUD, S.; Sobre a psicoterapia 2. ed.; v. 7 Edição Standard Brasileira das Obras Completas. Rio de Janeiro: Imago, 1989. ; Sobre o início do tratamento 2. ed.; v. 12 Edição Standard Brasileira das Obras Completas. Rio de Janeiro: Imago, 1989.

-; Sobre o narcisismo: uma introdução 2. ed.; v.14 Edição Standard Brasileira das Obras Completas. Rio de Janeiro: Imago, 1989.

LACAN, J. ; De uma questão preliminar a todo tratamento possivel da psicose. In: "Escritos", Rio de Janeiro: Jorge Zahar Editora, 1998.

, O Seminário: Livro 3 - As Psicoses, Rio de Janeiro: Jorge Zahar Editora, 1988

RAMOS, C. E. A. S. R.; As drogas e as psicoses: sobre a constituição do delírio e as toxicomanias. Curitiba: outubro/2001. 27 f. Trabalho de Graduação (Disciplina de Estágio em Pesquisa II) - desenvolvido no Centro de Estudos das Toxicomanias - Dr. Claude Olivenstein (CET), Curso de Psicologia, setor de Ciências Humanas, Letras e Artes; Universidade Federal do Paraná.

\section{Bibliografia Consultada}

CALliGARIS, C. Introdução a uma clínica diferencial das psicoses. Porto Alegre: Artes Médicas, 1989.

CZERMAK, M. Paixóes do objeto, estudo psicanalítico das psicoses. Porto alegre: $\quad$ Artes Médicas, 1991.

DESSUANT, P. O narcisismo. Rio de Janeiro: Imago Editora, 1992

FREUD, S. Neurose e Psicose. In: Obras psicológicas completas de Sigmund

Freud: Edição Standart brasileira. volume XIX (1923-1925). Rio de Janeiro:

Imago Editora, 1996.

KAUFMANN, P. Dicionário enciclopédico de psicanálise, o legado de Freud e Lacan. Rio de Janeiro: Jorge Zahar Editora, 1996.

LACAN, J. , "Escritos”, Rio de Janeiro: Jorge Zahar Editora, 1998. 
--an , O Seminário: Livro 3 - As Psicoses, Rio de Janeiro: Jorge Zahar Editora, 1988

-.--, O Seminário: Livro 7 - A Ética da Psicanálise, Rio de Janeiro: Jorge Zahar Editora, 1991

LEMAIRE, A., Jacques Lacan: uma introdução. Rio de Janeiro: Editora Campus, 1989

MELMAN, C., Estrutura lacaniana das psicoses. Porto Alegre: Artes Médicas, 1991

PINHEIRO, R. M., "ELEDÁ": um caso de psicose. I Jornada de trabalho do Centro Mineiro de Toxicomanias. 1988.

RABINOVITCH, S., A foraclusão: presos do lado de fora. Rio de Janeiro: Jorge Zahar Editora, 2001

ROSENFELD, H. A., Impasse e interpretação: fatores terapêuticos e antiterapêuticos no tratamento psicanalítico de pacientes neuróticos, psicóticos e fronteiriços. Rio de Janeiro: Imago, 1988.

THIS, B., O pai: ato de nascimento. Porto Alegre: Artes Médicas, 1987 